\title{
Statistical Literacy Siswa SMP dalam Pembelajaran Matematika
}

\section{Firda Hariyanti ${ }^{1}$}

Institut Teknologi dan Sains Nahdlatul Ulama Pasuruan. Kabupaten Pasuruan, Jawa Timur, Indonesia. Email: hariyantifirda@gmail.com

\begin{abstract}
Abstrak
Melek terhadap informasi merupakan kebutuhan siswa untuk mengimbangi perkembangan IPTEK yang semakin pesat dan dinamis. Kemampuan statistical literacy menjadi tolak ukur untuk mengetahui siswa melek informasi. Adapun statistical literacy merupakan kemampuan memahami, menginterpretasikan, dan mengevaluasi informasi kontesktual secara kritis. Oleh karena itu, pentingnya mengindentifikasi statistical literacy siswa dan sejauh mana siswa dapat menggunakan informasi secara cerdas. Tujuan penelitian ini untuk mengungkapkan kemampuan statistical literacy siswa SMP pada pembelajaran matematika berdasarkan empat indikator, yaitu (1) pemahaman terminologi dasar statistika dan peluang untuk memahami informasi; (2) menafsirkan pesan statistik; (3) menyimpulkan dan membuat keputusan; (4) mengevaluasi informasi secara kritis. Metode penelitian yang digunakan adalah deskriptif. Subjek penelitian adalah siswa kelas VII-D SMP Negeri 2 Bangkalan. Hasil penelitian menunjukkan siswa memiliki pemahaman terminologi dasar statistika dan peluang yang baik, siswa mampu menginterpretasikan pesan statistik dalam bentuk grafik, namun sebagian besar siswa lemah untuk menafsirkan data yang disajikan dalam bentuk diagram lingkaran. Cara mengevaluasi dan penarikan kesimpulan yang dibuat sebagian besar siswa kurang didasari perhitungan secara matematis, sehingga berdampak dalam membuat keputusan yang kurang efisien. Kesimpulannya siswa SMP memiliki kemampuan statistical literacy dalam memahami, menginterpretasikan, dan menarik kesimpulan, namun belum sampai pada tahap mengevaluasi informasi secara kritis.
\end{abstract}

\section{Student's Statistical Literacy of Junior high school in Learning Mathematics}

\begin{abstract}
Information literacy is a student's need to keep pace with the increasingly rapid and dynamic development of science and technology. The ability of statistical literacy becomes a benchmark to find out information literacy students. Statistical literacy is the ability of understanding, interpreting, and evaluating information critically. The ability of statistical literacy is a benchmark in order to know students' awareness about information. Therefore, it is important to identify students' statistical literacy abilities and how far students are able to use the information in a better way. The aim of this study is to reveal the students' statistical literacy ability of junior high school students in mathematics class, based on four indicators, (1) understanding the basic terminology of statistics and the probability to understand information; (2) interpreting statistical messages; (3) making conclusion and a decision; (4) evaluating information critically. The research method is descriptive. The subjects of this research are 7th grade students of SMPN 2 Bangkalan. The results show that, students have good understanding of statistics and probability terminology, students were able to interpret statistical messages in graphical form, but most of the students are weak to interpret data that is presented in the form of pie charts. The ability to evaluate and make a conclusion that is made by most students is not based on mathematical calculations, so that the effect in making decisions is not efficient. The conclusion is the subjects have statistical literacy ability in understanding, interpreting, and making conclusions, but have not reached the stage of evaluating information critically
\end{abstract}

Keywords: Statistical Literacy, Student's Statistical Literacy of Junior high school. 


\section{PENDAHULUAN}

Penguasaan informasi, media, dan teknologi merupakan keterampilan strategis yang harus dimiliki siswa dalam menghadapi tantangan abad ke 21. Pentingnya penguasaan informasi menjadi ujung tombak siswa dalam mengimbangi pesatnya perkembangan ilmu pengetahuan dan teknologi. Media online maupun media cetak menjadi pilihan siswa untuk memenuhi segala kebutuhan sehari-hari dalam mencari informasi. Akan tetapi, dapatkah siswa mengolah informasi dengan baik, memahami, menginterpretasikan, menganalisis serta menggunakan informasi dalam pengambilan keputusan. Hal tersebut berkaitan dengan maraknya informasi yang telah disajikan dalam bentuk statistik deskriptif, seperti halnya informasi-informasi yang disajikan dalam bentuk tabel maupun grafik.

Penyajian informasi yang disajikan dalam bentuk statistik deskriptif lebih efisien dan menjadi pilihan dalam menyampaikan informasi kepada masyarakat terkait kesehatan, kebijakan publik maupun pendidikan. Sebagaimana Indah menyatakan bahwa data atau informasi merupakan bagian yang sangat penting dalam menggunakan statistik. ${ }^{1}$ Sebagai contoh sederhana penyajian nilai UN lima tahun terakhir, jumlah pasien di rumah sakit perbulan, dan data jumlah penduduk pada setiap tahun, tentu data tersebut akan lebih mudah disajikan dalam bentuk tabel, grafik atau diagram daripada dalam bentuk deskripsi. Peran statistical literacy untuk melek informasi sebagaimana dikemukakan oleh Lehohla bahwa literasi statistis adalah kemampuan individu dan atau masyarakat untuk membaca dan memahami informasi kuantitatif seperti indikator dan indeks. ${ }^{2}$ Pada dasarnya pesan statistik disampaikan melalui teks tertulis dan mengharuskan pembaca melek statistis untuk menganalisa informasi dari tabel maupun grafis. $^{3}$

Emansipasi yang dapat diberikan masyarakat yaitu dengan melek statistis, memungkinkan tidak hanya dapat membaca data, tetapi juga dapat mengevaluasi dan mengkomunikasikan informasi yang disajikan dalam bentuk statistik. Schield "Statistical literacy is a competency just like reading, writing or speaking and Statistical literacy involves two reading skills: comprehension and interpretation". ${ }^{4}$ Statistical literacy merupakan kemampuan yang harus dimiliki semua kalangan tanpa terkecuali siswa untuk membantu mengolah informasi secara cerdas. Statistical literacy adalah kemampuan membaca, memahami, dan mengkomunikasikan informasi statistik. ${ }^{5}$ Sebagai contoh, jika siswa dihadapkan pada informasi yang disajikan pada grafik gambar 1, dan adanya suatu pernyataan berikut, "bahwa jumlah siswa yang putus sekolah pada jenjang SMK tahun 2016/2017 mencapai dua kali lipat siswa pada jenjang SMA tahun 2016/2017. Apakah pernyataan tersebut benar? Berikan alasanmu”.

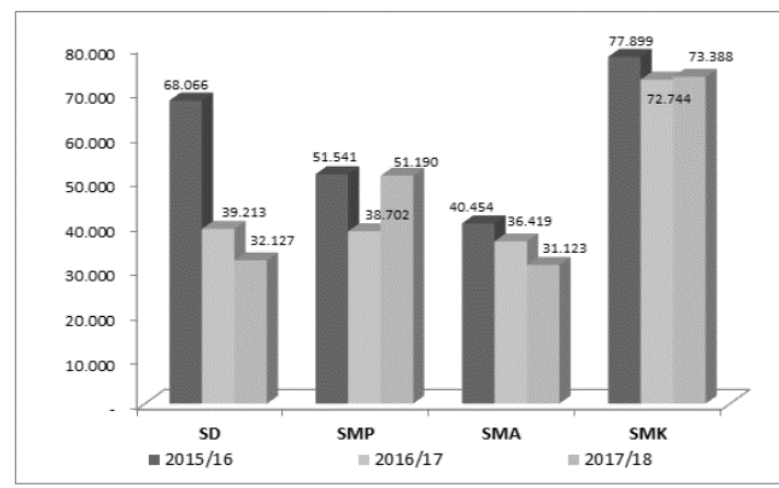

Gambar 1. Perkembangan jumlah siswa putus sekolah menurut jenjang pendidikan

\footnotetext{
${ }^{1}$ N I Meilia and Nur Indah, "Statistik Deskriptif Dan Induktif,” Yogyakarta: Graha Ilmu, 2010.

${ }^{2}$ Pali Lehohla, "Promoting Statistical Literacy: A South African Perspective," 2002.

${ }^{3}$ Idoo Gal, "Statistical Literacy, Meanings, Components, Responsibilities. The Challenge of Developing Statistical Literacy, Reasoning and Thinking” (Kluwer Academic Publishers, 2004).

${ }^{4}$ Milo Schield, "Statistical Literacy: Thinking Critically about Statistics," Of Significance 1, no. 1 (1999):

${ }^{5}$ Laura Ann Ziegler, Reconceptualizing Statistical Literacy: Developing an Assessment for the Modern Introductory Statistics Course, 2014.
} $15-20$. 
Siswa yang melek statistis tentu akan menjawab bahwa pernyataan tersebut kurang tepat, terlihat pada grafik tampak mencapai dua kali lipat, namun setelah melibatkan perhitungan matematis bahwa jumlah siswa putus sekolah pada jenjang SMK tahun 2016/17 adalah 72.744, sedangkan jika dijumlah dua kali lipat siswa putus sekolah jenjang SMA tahun 2016/17 adalah 72.838. Hal ini yang diharapkan terhadap siswa untuk dapat melek statistis, tidak hanya dapat membaca grafik, namun dapat mengevaluasi informasi secara kritis dengan melibatkan perhitungan matematis yang tepat. Sebagaimana Batanero dan Borovcnik yang menekankan bahwa melek statistis dapat mendeteksi kemungkinan kesalahan informasi. Selain itu, penyajian data yang tepat juga bagian dari melek statistis. ${ }^{6}$ Sebagai contoh, "apa grafik yang tepat dan efisien untuk penyajian data berat seorang bayi dalam 5 tahun terakhir?". Jawaban yang diharapkan dari siswa adalah grafik garis. Grafik garis paling tepat untuk menggambarkan keadaan yang kontinu atau berkelanjutan sehingga terlihat jelas perubahan data dari waktu ke waktu.

Statistical literacy mencakup keterampilan dasar yang penting, melibatkan istilah dasar statistik, memahami penggunaan simbol-simbol statistik, mengenali, dan mampu dalam memahami informasi statistik atau hasil penelitian. Keterampilan tersebut termasuk mampu mengatur data, membuat dan menampilkan tabel, menginterpretasikan serta merepresentasikan data yang berbeda juga menyatakan bahwa literasi statistik merupakan kemampuan untuk menginterpretasi, ${ }^{7}$ mengevaluasi secara kritis, dan mengkomunikasikan informasi dan pesan statistik. ${ }^{8}$ Berdasarkan pendapat tersebut bahwa melek statistis tidak hanya kemampuan dalam menginterpretasikan, namun ketepataan mengevaluasi informasi atau data yang disajikan. Wallman menambahkan bahwa literasi statistis adalah kemampuan untuk memahami dan mengevaluasi secara kritis hasil statistik yang menyebar atau yang ada dalam kehidupan sehari-hari, ditambah dengan kemampuan mengapresiasi berpikir statistik dapat berkonstribusi membuat keputusan publik, private, profesional dan pribadi. ${ }^{9}$ Hal senada dikemukakan oleh Ridgway, Nicholson \& McCusker literasi statistis adalah lebih dari menerapkan mekanis statistik, namun menekankan pada kemampuan membaca dengan menafsirkan secara kritis menggunakan statistik sebagai bukti dalam argumen berbagai konteks sehari-hari dan profesional. ${ }^{10}$

Literasi statistis tidak bisa dipandang sebagai keterampilan yang dibutuhkan oleh beberapa orang tertentu, karena literasi statistis adalah pengetahuan penting yang dibutuhkan dan harus dikembangkan mulai pada usia dini serta dibangun disepanjang jenjang sekolah. Hal tersebut merujuk bahwa seharusnya siswa telah dibekali kemampuan melek statistis disetiap jenjang sekolah. Dipertegas oleh Garfield \& Ben-Zvi bahwa literasi statistis merupakan kemampuan utama yang diharapkan dari warga negara dalam masyarakat yang sarat akan informasi, dan yang disebut sebagai hasil dari kegiatan pembelajaran sekolah. ${ }^{11}$ Tingkat dasar literasi statistis termasuk dalam profesional pendidikan calon guru, akan tetapi sudah sewajarnya dan diharapkan utamanya bagi guru matematika dapat memberikan dukungan dalam mengembangkan melek statistis di sekolah mereka. ${ }^{12}$ Pada intinya literasi statistis merupakan kemampuan memahami, menginterpretasikan dan mengevaluasi informasi sehingga dapat menjadi bahan dalam menarik kesimpulan serta pengambilan keputusan. Dan merupakan bekal bagi siswa dalam kehidupan bermasyarakat yang seharusnya diasah untuk melek statistis pada setiap jenjang sekolah.

Mengingat pentingnya statistical literacy yang harus dikembangkan sejak pada usia dini, maka perlu adanya identifikasi awal untuk mengetahui statistical literacy siswa. Hal ini sebagai bentuk indikasi perlu dilakukan intervensi dalam mengembangkan statistical literacy siswa. Adapun Forum

${ }^{6}$ Carmen Batanero and Manfred Borovcnik, Statistics and Probability in High School (Springer, 2016).

${ }^{7}$ Dani Ben-Zvi and Joan B Garfield, The Challenge of Developing Statistical Literacy, Reasoning and Thinking (Springer, 2004).

8 Gal, "Statistical Literacy, Meanings, Components, Responsibilities. The Challenge of Developing Statistical Literacy, Reasoning and Thinking."

${ }^{9}$ Katherine K Wallman, "Enhancing Statistical Literacy: Enriching Our Society," Journal of the American Statistical Association 88, no. 421 (1993): 1-8.

${ }^{10}$ Batanero and Borovcnik, Statistics and Probability in High School.

11 Joan Garfield and Dani Ben-Zvi, Developing Students' Statistical Reasoning: Connecting Research and Teaching Practice (Springer Science \& Business Media, 2008).

${ }^{12}$ Helen Chick and Robyn Pierce, "The Statistical Literacy Needed to Interpret School Assessment Data.," Mathematics Teacher Education and Development 15, no. 2 (2013): n2. 
Riset Internasional pada Statistical Reasoning, Thingking, and Literacy (SRTL) juga mendukung dengan mulai mengembangkan studi penelitian terkini dan inovatif yang memeriksa sifat dan pengembangan literasi statistis, berpikir dan penalaran, serta menyelidiki tantangan pendidik pada semua level dalam mengembangkan tujuan pembelajaran yang dibutuhkan siswa. ${ }^{13}$ Oleh karena itu, perlu dilakukan penelitian dalam mengungkapkan kemampuan statistical literacy siswa pada sekolah menengah. Sekolah Menengah Pertama (SMP) menjadi jenjang pilihan dan sangat cocok untuk mengindentifikasi statistical literasi siswa. Piaget menyatakan pada usia 11- ke atas berada pada tahap formal, artinya pada tahap ini anak telah memiliki kemampuan berpikir abstrak, mampu merumuskan banyak alternatif hipotesis dalam menanggapi masalah, berpikir kombinatorial dan berfikir reflektif. ${ }^{14}$

Tujuan penelitian ini untuk mengindentifikasi dan mendeskripsikan kemampuan statistical literacy siswa SMP pada pembelajaran matematika berdasarkan empat indikator. Manfaat yang diharapkan dari hasil penelitian ini antara lain; pertama dapat menjadi masukan bagi guru untuk melakukan intervensi mengembangkan kemampuan statistical literacy secara optimal dalam pembelajaran matematika. Kedua, sebagai data untuk pemerhati pendidikan matematika atau peneliti selanjutnya untuk mengungkap kemampuan statistical literacy siswa dalam skala yang lebih besar. Dan ketiga, hasil penelitian diharapkan sebagai masukan untuk pengembang kurikulum atau para peneliti selanjutnya sehingga dapat mengembangkan perangkat pembelajaran dalam meningkatkan kemampuan statistical literacy siswa pada setiap jenjang pendidikan.

\section{METODE}

\section{Jenis Penelitian}

Jenis penelitian ini adalah penelitian deskriptif. Peneliti akan mendeskripsikan kemampuan siswa dalam menyelesaikan instrumen tes statistical literacy yang terdiri dari empat indikator. Yaitu, (1) memahami terminologi dasar statistika dan peluang untuk memahami informasi; (2) menafsirkan pesan statistik; (3) menyimpulkan dan membuat keputusan; (4) mengevaluasi informasi kontekstual secara kritis. Hasil penelitian ini mengungkapkan fenomena alamiah yang dilakukan oleh subjek dalam menyelesaikan instrumen tes statistical literacy.

\section{Subjek dan Prosedur}

Subjek penelitian ini adalah siswa kelas VII SMP yang terdiri dari 40 siswa. Instrumen yang digunakan adalah instrumen tes statitical literacy yang terdiri dari 12 soal pilihan ganda dan 3 soal uraian. Prosedur penelitian yang dilakukan oleh peneliti ada tiga tahap, (1) tahap perencanaan dengan menyusun instrumen tes statistical literacy dan melakukan observasi terhadap siswa yang akan dijadikan subyek penelitian, (2) tahap pelaksanaan, siswa diberikan instrumen tes statistical literacy dengan waktu 80 menit, (3) tahap analisis data, pada tahap ini hasil penelitian dianalisis menggunakan teknik analisis data yang digunakan pada penelitian deskriptif. Kemudian, hasil analisis data digunakan untuk mengungkap kemampuan statistical literacy siswa.

\section{Instrumen Tes}

Instrumen tes statitical literacy merupakan instrumen untuk mengukur kemampuan statistical literacy siswa. Penyusunan instrumen tes statistical literacy merujuk pada penjabaran indikator statistical literacy yang terukur. Instrumen tes memiliki bukti validasi yang valid dan reliabel dengan nilai SEM 1,293. Pembuatan kisi-kisi melalui tahapan kajian teori tentang statistical literacy, kemudian disintesis dan diperoleh indikator statistical literacy. Selanjutnya indikator statistical literacy dipadukan dengan indikator kompetensi dasar siswa SMP yang dijadikan sebagai indikator soal pada tes statistical literacy. Adapun kisi-kisi instrumen tes dapat dilihat pada Tabel 1.

Berdasarkan Tabel 1 tersebut, bahwa indikator statistical literacy terlihat pada setiap nomor soal. Indikator-indikator soal tes statistical literacy dibagi dalam tiga konteks yaitu pribadi, sekolah, dan masyarakat. Instrumen tes disusun sebanyak 15 soal dan Setiap soal mewakili indikator statistical litercay. SL 1 merupakan pemahaman terminologi dasar statistika dan peluang, SL 2 merupakan menafsirkan (menginterpretasikan) dan mengkomunikasikan pesan statistik, SL 3 merupakan

\footnotetext{
${ }^{13}$ Garfield and Ben-Zvi, Developing Students' Statistical Reasoning: Connecting Research and Teaching Practice.

${ }^{14}$ Robert E Slavin and Nicola Davis, Educational Psychology: Theory and Practice (Pearson/Allyn \& Bacon, 2006).
} 
menyimpulkan dan membuat keputusan data, dan SL 4 mengevaluasi informasi secara kritis. Terlihat juga pada Tabel 1 bahwa konteks lebih dominan pada sekolah dan masyarakat, sedangkan untuk konteks pribadi hanya diwakili oleh satu soal. Hal ini meninjau pendapat Watson bahwa keterlibatan dengan konteks yang semakin kompleks atau asing bagi siswa, maka semakin tinggi pada tingkatan kinerja statistical literacy. Watson membagi menjadi tiga konteks dalam statistical literacy. ${ }^{15}$ Pertama, ada tugas atau soal, misalnya terkait dengan dadu atau membaca tabel. Kedua, beberapa soal atau tugas yang diatur dalam konteks yang dianggap akrab atau familiar bagi siswa dari pengalaman mereka di sekolah, seperti melakukan survei sekolah setempat. Ketiga, ada item soal atau penyajian data yang termuat dari media yang berbeda dengan konteks sekolah.

Selain itu, penyusunan kunci jawaban pedoman penskoran instrumen tes statistical literacy soal pilihan ganda dilengkapi dengan jawaban pengecoh. Siswa menjawab benar pada soal pilihan ganda mendapatkan skor 1 dan skor 0 jika salah. Sedangkan untuk soal dalam bentuk uraian, skor siswa menjawab benar disesuaikan dengan rubrik pedoman penilaian uraian dan memperhatikan ketepatan argumen siswa. Selanjutnya jawaban siswa disesuaikan dengan empat indikator statistical literacy dalam mendeskripsikan kemampuan siswa melek statistis.

\section{Teknik Analisis Data}

Teknik analisis data penelitian ini menggunakan statistik deskriptif dengan menghitung rata-rata dan persentase pada setiap masing-masing butir soal tes statistical literacy. Sistematika analisis data yang pertama adalah mengumpulkan data atau pengelompokan informasi yang diberikan oleh subjek. Setelah data terkumpul, dihitung rata-rata siswa menjawab benar dan dipresentasekan. Hasil perhitungan selanjutnya dianalisis dengan cara mendeskripsikan atau menggambarkan data yang telah terkumpul sebagaimana adanya. Kedua, mereduksi data yang kurang perlu atau tidak relevan. Ketiga, melakukan pemaparan atau penyajian data dan interpretasi data sebagai proses penulisan data dalam penilaian yang dikonversikan terhadap indikator statistical literacy. Keempat, melakukan penarikan kesimpulan yang dimasudkan untuk medeskripsikan kemampuan statistical literacy siswa SMP. Proses penarikan kesimpulan dimaknai sebagai perumusan dari hasil penelitian yang didasarkan pada hasil pembahasan terhadap data yang terkumpul.

Table 1. Kisi-kisi instrumen tes statistical literacy

\begin{tabular}{|c|c|c|c|c|c|c|c|c|}
\hline \multirow[b]{2}{*}{ Indikator } & \multirow{2}{*}{$\begin{array}{l}\text { No } \\
\text { Soal }\end{array}$} & \multicolumn{4}{|c|}{ Statistical literacy } & \multicolumn{3}{|c|}{ Konteks statistical literacy } \\
\hline & & $\begin{array}{l}\text { SL } \\
1\end{array}$ & $\begin{array}{l}\text { SL } \\
2\end{array}$ & $\begin{array}{l}\text { SL } \\
3\end{array}$ & $\begin{array}{l}\text { SL } \\
4\end{array}$ & Pribadi & Sekolah & Masyarakat \\
\hline $\begin{array}{l}\text { Menyebutkan cara yang efektif untuk } \\
\text { mengumpulkan data }\end{array}$ & 1 & $\sqrt{ }$ & & & & & $\sqrt{ }$ & \\
\hline $\begin{array}{l}\text { Menyebutkan teknik penyajian data } \\
\text { yang efektif }\end{array}$ & 2 & $\sqrt{ }$ & & & & & & $\sqrt{ }$ \\
\hline $\begin{array}{l}\text { Menyimpulkan informasi data dari } \\
\text { diagram lingkaran }\end{array}$ & 7 & & & $\sqrt{ }$ & & & & $\sqrt{ }$ \\
\hline $\begin{array}{l}\text { Menyimpulkan informasi data dari } \\
\text { diagram batang }\end{array}$ & 9 & & & $\sqrt{ }$ & & & & $\sqrt{ }$ \\
\hline $\begin{array}{l}\text { Menyimpulkan informasi data dari } \\
\text { diagram garis }\end{array}$ & 10 & & & $\sqrt{ }$ & & & & $\sqrt{ }$ \\
\hline $\begin{array}{l}\text { Menginterpretasikan data pada } \\
\text { diagram }\end{array}$ & 6,11 & & $\sqrt{ }$ & & & & $\sqrt{ }$ & \\
\hline $\begin{array}{l}\text { Membedakan peggunaan teknik } \\
\text { penyajian data yang paling sesuai dari } \\
\text { sekumpulan data }\end{array}$ & 3 & $\sqrt{ }$ & & & & & & $\sqrt{ }$ \\
\hline Membedakan populasi dan sampel & 15 & & $\sqrt{ }$ & & & & & $\sqrt{ }$ \\
\hline $\begin{array}{l}\text { Menyajikan data dari bentuk tabel ke } \\
\text { bentuk diagram }\end{array}$ & 4 & & $\sqrt{ }$ & & & & $\sqrt{ }$ & \\
\hline
\end{tabular}

${ }^{15}$ Jane M Watson, Statistical Literacy at School: Growth and Goals (Routledge, 2013). 
EKSPOSE: Jurnal Penelitian Hukum dan Pendidikan, 18 (2), Desember 2019 - 916

Firda Hariyanti

\begin{tabular}{|c|c|c|c|c|c|c|c|}
\hline \multirow[b]{2}{*}{ Indikator } & \multirow{2}{*}{$\begin{array}{l}\text { No } \\
\text { Soal }\end{array}$} & \multicolumn{3}{|c|}{ Statistical literacy } & \multicolumn{3}{|c|}{ Konteks statistical literacy } \\
\hline & & $\begin{array}{ll}\text { SL } & \text { SL } \\
1 & 2\end{array}$ & $\begin{array}{l}\text { SL } \\
3\end{array}$ & $\begin{array}{l}\text { SL } \\
4\end{array}$ & Pribadi & Sekolah & Masyarakat \\
\hline $\begin{array}{l}\text { Menyajikan sekumpulan data ke dalam } \\
\text { bentuk table }\end{array}$ & 5 & $\sqrt{ }$ & & & & $\sqrt{ }$ & \\
\hline $\begin{array}{l}\text { Membuat keputusan dari informasi } \\
\text { yang disajikan dalam bentuk tabel }\end{array}$ & 8 & & & $\sqrt{ }$ & & $\sqrt{ }$ & \\
\hline $\begin{array}{l}\text { Membuat keputusan dari informasi } \\
\text { yang disajikan dalam bentuk diagram } \\
\text { untuk menyelesaikan masalah }\end{array}$ & 12 & $\sqrt{ }$ & & $\sqrt{ }$ & $\sqrt{ }$ & & \\
\hline $\begin{array}{l}\text { Memeriksa kesimpulan dari informasi } \\
\text { yang disajikan dalam bentuk tabel atau } \\
\text { diagram }\end{array}$ & 13 & & & $\sqrt{ }$ & & & $\sqrt{ }$ \\
\hline $\begin{array}{l}\text { Memeriksa kebenaran penyajian data } \\
\text { dari masalah yang berkaitan dengan } \\
\text { konteks }\end{array}$ & 14 & & & $\sqrt{ }$ & & & $\sqrt{ }$ \\
\hline
\end{tabular}

\section{HASIL DAN PEMBAHASAN}

Data yang diperoleh dari hasil uji instrumen tes statistical literacy, selanjutnya dianalisis menggunakan statistik deskriptif. Skor siswa yang dihitung dalam bentuk persentase pada masingmasing indikator statistical literacy menjadi bahan dalam mendeskripsikan atau menggambarkan hasil penelitian. Ketercapaian indikator statistical literacy dapat dilihat dari rata-rata siswa yang menjawab benar dan dikonversikan dalam bentuk persentase pada setiap butir soal. Pembahasan hasil penelitian terbatas pada jawaban siswa yang rata-rata menjawab salah atau terkecoh pada distraktor pilihan butir soal tes statistical literacy tidak mencapai jawaban benar lebih dari 75\%. Selain itu, akan dibahas analisis kemungkinan jawaban siswa salah dalam menggunakan perhitungan secara matematis.

Soal tes statistical literacy memuat 12 soal pilihan ganda dan tiga soal uraian. Indikator statistical literacy dalam penelitian ini meliputi; (1) pemahaman terminologi dasar statistika dan peluang, butir soal yang mewakili nomor 1, 2, 3, dan 15; (2) menafsirkan dan mengkomunikasikan data , butir soal yang mewakili nomor $4,5,6$, dan 11 ; (3) menyimpulkan dan membuat keputusan, butir soal yang mewakili nomor 7, 8, 9, 10, dan 12; (4) mengevaluasi informasi secara kritis, butir soal yang mewakili nomor 13 dan 14. Rekapitulasi persentase ketercapaian indikator soal nomor 1 sampai 12 ditunjukkan pada tabel 2.

Tabel 2. Rekapitulasi Ketercapaian Indikator Statistical Literacy

\begin{tabular}{ccc}
\hline No Butir Soal & $\begin{array}{c}\text { Banyak Siswa } \\
\text { Menjawab } \\
\text { Benar }\end{array}$ & Persentase \\
\hline 1 & 32 & $80 \%$ \\
2 & 30 & $75 \%$ \\
3 & 36 & $90 \%$ \\
4 & 38 & $95 \%$ \\
5 & 40 & $100 \%$ \\
6 & 36 & $90 \%$ \\
7 & 30 & $75 \%$ \\
8 & 39 & $98 \%$ \\
9 & 39 & $98 \%$ \\
10 & 37 & $93 \%$ \\
11 & 22 & $55 \%$ \\
12 & 29 & $73 \%$ \\
\hline
\end{tabular}

Berdasarkan Tabel 2 diketahui bahwa ada dua indikator dengan persentase $<75 \%$, yaitu butir soal nomor 11 dan 12. Soal nomor 11 merupakan indikator menafsirkan atau menginterpretasikan data dan nomor 12 merupakan indikator menyimpulkan dan membuat keputusan. Adapun soal nomor 11 ditunjukkan pada Gambar 2. 


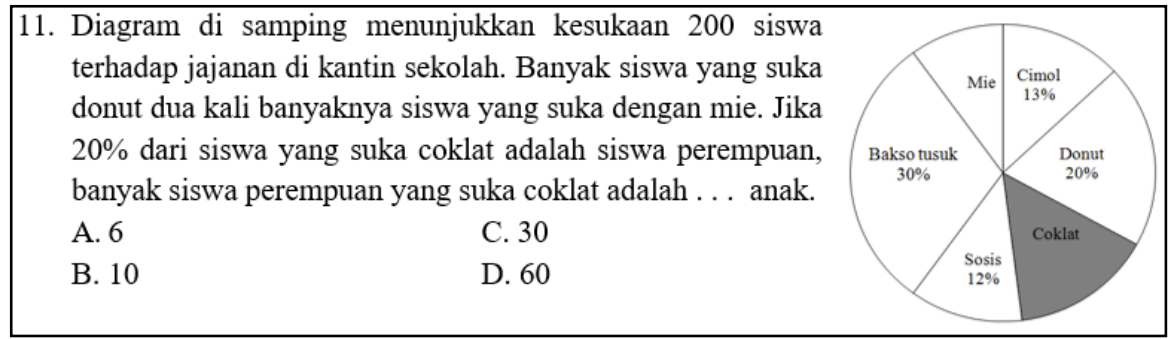

Gambar 2. Soal Tes Nomor 11

Dari soal nomor 11 tersebut, siswa menjawab benar hanya mencapai persentase 55\%. Jawaban yang benar adalah pilihan "A", namun masih banyak siswa yang terkecoh dengan pilihan jawaban B, C, atau D. Beberapa siswa salah konsep dengan menggunakan informasi soal pada pilihan " $\mathrm{B}$ " yaitu dengan menghitung $\frac{20}{200} \times 100=10$. Sedangkan untuk pilihan yang paling banyak dipilih siswa adalah jawaban "C", siswa kurang cermat memperhatikan pertanyaan soal, dengan tidak menghitung $20 \%$ dari banyaknya siswa yang suka coklat, yaitu $\frac{15}{100} \times 200=30$ dan tidak melanjutkan perhitungan $20 \%$ dari 30. Sementara ada juga siswa yang memilih jawaban " $D$ " dengan perhitungan yang kurang teliti, $\frac{20}{100} \mathrm{x}$ $30=60$.

Indikator soal selanjutnya yang belum mencapai $75 \%$ adalah membuat keputusan data yang diwakili soal nomor 12. Siswa diminta untuk membuat keputusan dari informasi yang disajikan dalam bentuk tabel yang terdapat pada butir soal nomor 12 untuk memilih jawaban dengan alasan yang tepat dan cara yang paling efisien. Semua pilihan jawaban pada soal nomor 12 adalah benar dan sudah tepat. Namun soal menekankan untuk menggunakan cara yang efisien, hal ini karena keputusan yang baik adalah yang paling efektif dan efisien. Butir soal nomor 12 dibuat untuk dapat melihat siswa melek statistis dengan indikator menyimpulkan dan membuat keputusan dari suatu data.

Pilihan jawaban dengan alasan yang tepat dan cara yang paling efisien adalah "D". Sedangkan $27 \%$ siswa membuat keputusan yang kurang efisien dengan memilih jawaban A, B, atau C. Pilihan A kurang efisien, karena album 1, 5, dan 7 adalah $200 \mathrm{Mb}$, sedangkan yang dibutuhkan hanya $195 \mathrm{Mb}$. Untuk pilihan B juga kurang efisien, karena album 1, 3, dan 6 adalah 200 Mb. Sementara untuk siswa yang memilih pilihan jawaban $C$ kurang teliti, karena tidak membaca ruang kosong, jadi album 4, 5, dan 6 adalah $375 \mathrm{Mb}$, sedangkan ruang kosong yang tersedia adalah $180 \mathrm{Mb}$.

Meninjau dari hasil jawaban siswa pada butir soal No 11 dan No 12 membuktikan bahwa siswa sebenarnya mampu untuk membaca data dan menginterpretasikan data. Namun, melek statistis sebagian besar siswa tidak menggunakan perhitungan secara matematis dalam menyimpulkan dan mengambil keputusan, sehingga jawaban siswa terjebak pada distraktor dan kurang tepat untuk membuat keputusan. Hal tersebut, membenarkan Shaughnessy juga mengungkapkan banyak siswa yang dapat membaca dan memahami tabel, charts dan grafik, dan melakukan prosedur untuk menentukan ukuran pemusatan data statistik, tetapi mereka tidak memiliki kemampuan konseptual untuk menafsirkan dan menarik kesimpulan dari grafik atau untuk membuat keputusan perhitungan yang tepat dalam menyelesaikan masalah-masalah atau situasi tertentu. ${ }^{16}$

Selain itu, pada soal uraian dengan indikator mengevaluasi informasi secara kritis adalah soal nomor 13 dan 14. Pada soal nomor 13, sebagian besar siswa dapat mengevaluasi informasi dengan baik, namun alasan yang digunakan siswa masih sebatas menginterpretasikan data. Berikut contoh jawabanjawaban siswa pada nomor 13 .

Ada juga seorang siswa yang dapat mengevaluasi secara kritis, melihat semua unsur dari tabel dan menggunakan perhitungan secara matematis. Hal ini yang diharapkan agar siswa dapat melek statistis tidak sebatas dalam menginterpretasikan. Siswa menunjukkan melek statistis dengan melihat semua komponen pada soal yang diberikan. Sehingga jawaban yang diberikan oleh siswa tidak hanya berdasarkan intuisi, namun didukung dengan perhitungan yang tepat dalam berargumen dan menganalisis data atau informasi. Jawaban siswa dapat dilihat pada Gambar 5.

${ }^{16}$ Hélia Oliveira et al., "Developing Statistical Literacy: Student Learning and Teacher Education,” 2015. 


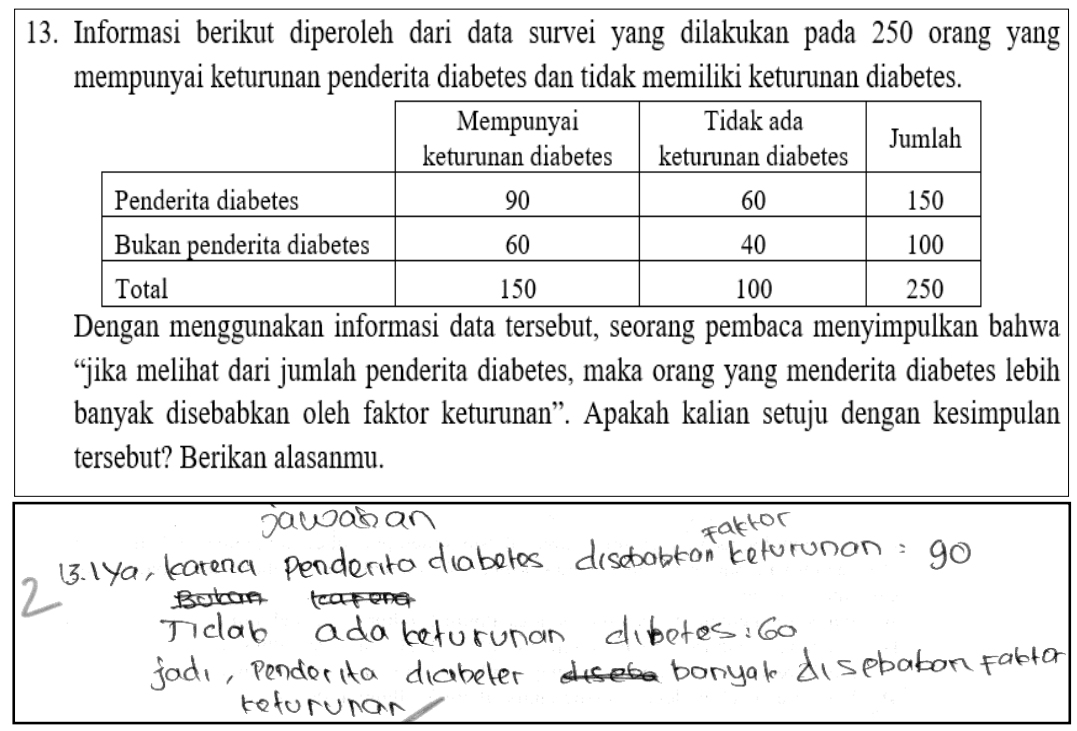

Gambar 3. Contoh jawaban siswa 1 pada soal nomor 13

Selanjutnya untuk anaslis jawaban siswa pada soal nomor 14 diketahui bahwa siswa dapat mengevaluasi dengan baik penyajian data dan kesimpulan yang ada pada soal. Namun demikian sebagian besar siswa hanya dapat mengevaluasi tetapi tidak melibatkan perhitungan matematis dalam menarik kesimpulan. Sebaliknya, berikut contoh salah satu jawaban siswa yang dapat mengevaluasi dengan baik dengan melibatkan perhitungan matematis pada Gambar 4.

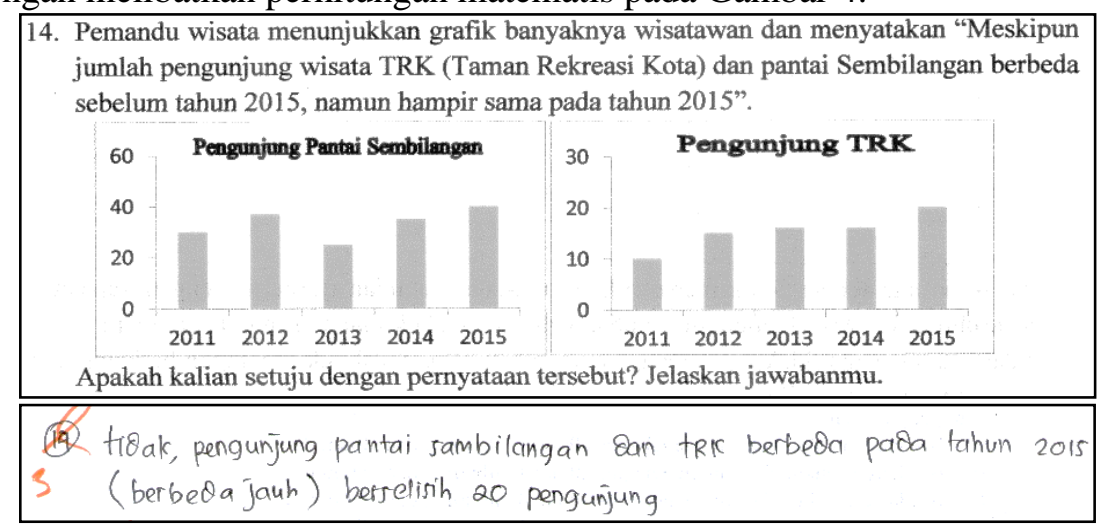

Gambar 4. Contoh jawaban siswa 1 pada soal nomor 14

Sementara, untuk soal uraian nomor 15 adalah menentukan populasi dan sampel dari konteks kehidupan sehari-hari. Sebagian besar siswa dapat menentukan populasi dan sampel, namun untuk pertanyaan pada poin $\mathrm{C}$ nomor 15, yaitu menafsirkan dari keterangan populasi dan sampel yang diperoleh sebelumnya, jawaban siswa masih kurang tepat. Contoh jawaban siswa pada soal nomor 15 ditunjukkan pada Gambar 5.

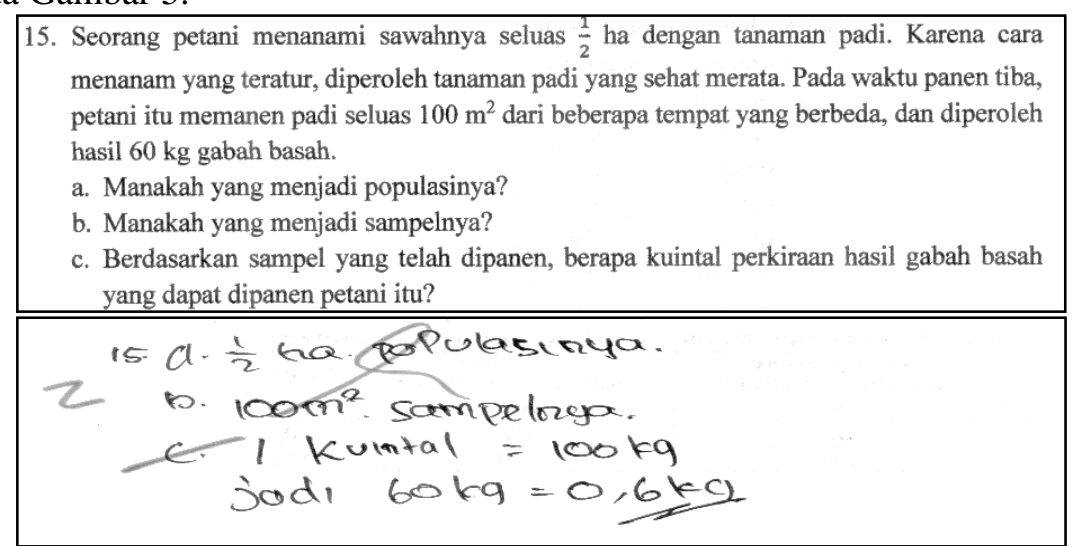

Gambar 5. Contoh jawaban siswa 1 pada soal nomor 15 
Jawaban yang tepat pada poin C nomor 15 adalah $\frac{60}{100} \times 5000=3000 \mathrm{~kg}=30$ kuintal. Dua jawaban siswa yang terlihat pada Gambar 7 dan 8 mewakili sebagian besar siswa dalam menjawab soal nomor 15.

Secara keseluruhan berdasarkan hasil dan pembahasan menunjukkan kemampuan siswa pada indikator statistical litercay pemahaman terminologi dasar statistika dan peluang serta menafsirkan data atau menginterpretasikan data memilki kemampuan yang baik. Tetapi, pada indikator statistical literacy mengevaluasi secara kritis, menyimpulkan data dan mengambil keputusan dari informasi yang diperoleh, sebagian besar siswa masih lemah. Hal tersebut membenarkan hasil penelitian dari Yolcu mengungkapkan kemampuan literasi statistis siswa sekolah menengah masih rendah ditunjukkan dengan rata-rata keseluruhan $0,32 .{ }^{17}$ Selanjutnya, untuk hasil yang diperoleh dari perhitungan Two-way ANOVA hasil menunjukkan tidak ada perbedaan yang signifikan untuk perbedaan tingkat kelas 6-8 di Selandia Baru. Hasil penelitian ini dapat digunakan sebagai acuan para pendidik di sekolah untuk mengembangkan dan mengasah kemampuan statistical literacy siswa dengan melibatkan konteks kehidupan sehari-hari yang lebih kompleks. Mengingat pentingnya siswa melek statistis untuk dapat melek juga terhadap IPTEK saat ini. Hal ini diperkuat oleh Chick \& Pierce yang paling utama bagi guru matematika sudah sewajarnya dan diharapkan dapat memberikan dukungan literasi statistis di sekolah mereka. ${ }^{18}$ Selain ium Watson \& Callingham menambahkan ada beberapa faktor yang berkontribusi terhadap pentingnya siswa mengembangkan keterampilan literasi statistis di tingkat sekolah. ${ }^{19}$ Pertama adalah harapan untuk berpartisipasi sebagai warga negara dalam era informasi dan cara pengambilan keputusan dari data yang cenderung didasarkan pada keterampilan yang penting dari bidang melek statistis.

\section{SIMPULAN}

Kemampuan statistical litercay siswa memahami terminologi dasar statistika dan peluang berdasarkan hasil analisis tes, yaitu siswa mampu menentukan cara memperoleh data yang efektif dan efisien, siswa juga tepat dalam memilih teknik penyajian data yang paling efektif untuk mewakili data. Namun demikian, masih ada siswa yang kurang tepat dalam menentukan teknik penyajian data menggunakan diagram garis. Selain itu, siswa memiliki kemampuan yang baik dalam membedakan populasi dan sampel dari sebuah informasi, tetapi tidak dapat melibatkan perhitungan secara matematis dengan menggunakan informasi yang dimiliki.

Kemampuan selanjutnya yang dimiliki siswa, yaitu siswa mampu menafsirkan atau menginterpretasikan pesan statistik yang disajikan dalam bentuk grafik, namun sebagian besar siswa lemah untuk menafsirkan data yang disajikan dalam bentuk diagram lingkaran. Evaluasi dan kesimpulan yang dibuat siswa kurang didasari perhitungan secara matematis, hal tersebut berdampak pada pengambilan keputusan yang kurang efisien. Kesimpulannya siswa SMP memiliki kemampuan statistical literacy dalam memahami, menginterpretasikan, dan menarik kesimpulan, namun belum sampai pada tahap mengambil keputusan dengan tepat dan mengevaluasi informasi secara kritis.

\section{DAFTAR PUSTAKA}

Batanero, Carmen, and Manfred Borovcnik. Statistics and Probability in High School. Springer, 2016. Ben-Zvi, Dani, and Joan B Garfield. The Challenge of Developing Statistical Literacy, Reasoning and Thinking. Springer, 2004.

Chick, Helen, and Robyn Pierce. "The Statistical Literacy Needed to Interpret School Assessment Data." Mathematics Teacher Education and Development 15, no. 2 (2013): n2.

Gal, Idoo. "Statistical Literacy, Meanings, Components, Responsibilities. The Challenge of Developing Statistical Literacy, Reasoning and Thinking." Kluwer Academic Publishers, 2004.

Garfield, Joan, and Dani Ben-Zvi. Developing Students' Statistical Reasoning: Connecting Research and Teaching Practice. Springer Science \& Business Media, 2008.

\footnotetext{
${ }^{17}$ Ayse Yolcu, "Middle School Students' Statistical Litteracy: Role of Grade Level and Gender.," Statistics Education Research Journal 13, no. 2 (2014).

${ }^{18}$ Chick and Pierce, "The Statistical Literacy Needed to Interpret School Assessment Data."

${ }^{19}$ Watson, Statistical Literacy at School: Growth and Goals.
} 
EKSPOSE: Jurnal Penelitian Hukum dan Pendidikan, 18 (2), Desember 2019 - 920

Firda Hariyanti

Lehohla, Pali. "Promoting Statistical Literacy: A South African Perspective," 2002.

Meilia, N I, and Nur Indah. "Statistik Deskriptif Dan Induktif." Yogyakarta: Graha Ilmu, 2010.

Oliveira, Hélia, A P Canavarro, A Henriques, and S Colaço. "Developing Statistical Literacy: Student Learning and Teacher Education," 2015.

Schield, Milo. "Statistical Literacy: Thinking Critically about Statistics." Of Significance 1, no. 1 (1999): $15-20$.

Slavin, Robert E, and Nicola Davis. Educational Psychology: Theory and Practice. Pearson/Allyn \& Bacon, 2006.

Wallman, Katherine K. "Enhancing Statistical Literacy: Enriching Our Society." Journal of the American Statistical Association 88, no. 421 (1993): 1-8.

Watson, Jane M. Statistical Literacy at School: Growth and Goals. Routledge, 2013.

Yolcu, Ayse. "Middle School Students' Statistical Litteracy: Role of Grade Level and Gender." Statistics Education Research Journal 13, no. 2 (2014).

Ziegler, Laura Ann. Reconceptualizing Statistical Literacy: Developing an Assessment for the Modern Introductory Statistics Course, 2014. 